\title{
'SELF-IE' MODULE: A COUNSELING PSYCHOLOGY INTERVENTION TO SUPPORT SELF-CHANGE AND WORK-PERFORMANCE ENHANCEMENT OF LOW-PERFORMING CIVIL SERVANTS
}

\author{
Abu Yazid Abu Bakar ${ }^{*}$, Hazaila Hassan², Salleh Amat ${ }^{3}$ \\ ${ }^{1 * 2,3}$ Faculty of Education, Universiti Kebangsaan Malaysia, 43600 Bangi, Malaysia. \\ Email:1*yazid3338@ukm.edu.my,2iyla16@yahoo.com, 3sallehba@ukm.edu.my
}

Article History: Received on $31^{\text {st }}$ March 2020, Revised on $17^{\text {th }}$ June 2020, Published on $5^{\text {th }}$ July 2020

\begin{abstract}
Purpose of the study: This study aims to examine the impact of a psychoeducational module known as the 'SELF-IE' module in helping low-performing civil servants. It is measured through the self-change variables of emotional stability, psycho-spirituality, and behavioral adjustment among respondents, who attended 2017 Self-Change and Well-Being Programme that used the 'SELF-IE' module as the intervention.
\end{abstract}

Methodology: This is a quasi-experimental study, in which the impact of the 'SELF-IE' module was determined by measuring the mean differences of the variables for both experimental and control groups. Data were collected from a total of 68 respondents using the Personal Well-Being Questionnaire (PWQ) consisting of 60 items divided into five different sections.

Main Findings: There is a significant mean difference in all three measured variables (emotional stability, psychospirituality, and behavioral adjustment) between both experimental and control groups, which means that the intervention using the 'SELF-IE' module has a positive impact in self-change of the respondents in those variables.

Applications of this study: The result of this study can provide useful information to help improve any selfdevelopment program for employees' particularly in public organizational settings. The information should be beneficial for organizational counselors or industrial psychologists, and human resources or training managers.

Novelty/Originality of this study: This study specifically enhances the human assessment performance in the Public Service Department (PSD), whereby the development of the 'SELF-IE' module has improved the current module used in public organizations' employee assistance program (EAP).

Keywords: Civil Servants, Counselling Psychology, Employee Assistance Program, Public Organization, Self-Change, Work Performance.

\section{INTRODUCTION}

Civil servants in Malaysia faced various issues in terms of human development which leads to a low level of commitment among some of them. Nowadays, current changes in society such as higher income and living rates, highly educated societies, and diverse customer demands, subsequently urging the public sector to provide better quality services in terms of broader options and flexibility (Marsidi \& Latip, 2007). Hence, the Public Service Department's (PSD) Circular Number 18/2005 (Psychological Applications in Civil Service) was issued to state the importance of establishing a holistic organizational support system in terms of counseling psychology interventions or employee assistance programs (EAPs), in order to improve the well-being quality of Malaysian civil servants.

Counseling at work is very important for an organization to help employees who are suffering from emotional, behavioral, and attitude problems. Carrol (1996) in his book the 'Workplace Counseling: A Systematic Approach to Employee Care' raises the question of what are the needs for counseling in the workplace. He stresses out that various approaches can be made to the preparation and implementation of counseling in the organization as it is determined by the organization itself, according to its' own suitability and adaptation. Furthermore, Organizational studies on employees' well-being revealed that low-performing employees need to be assisted to voluntarily change themselves because their holistic well-being is directly related to their overall working performance (Weiss, Westerhof \& Bohlmeijer, 2016; Myers, Sweeney \& Witmer, 2000).

Self-change is defined as the ability to measure variable situations which occur as a result of influences, reaction levels of physiological stresses, and self-supervision characteristic (Bandura, 1982). This behavioral change takes place in moments where lack of self-stability is caused by problems occurring in the organization whether connected to the individual worker, supervisor, or of the organization itself in general.

Thus, various suggestions are provided to assist treatments towards this change which includes introducing modules or programs that can solve the said problems. Intervention is defined as providing treatments and executing help in order to produce better performance, aimed especially towards a certain process in order to help the client identify the ongoing problems and to face the problems appropriately. 


\section{LITERATURE REVIEW}

In the Public Service Department's (PSD) Circular Number 18/2005 (Psychological Applications in Civil Service), intervention refers to steps taken in order to introduce positive changes in officers and staff such as counseling activities, intra colleague's guidance, and also mentoring. Intervention, therefore, is focused on individual persona including on ways to implement the various levels of theories' application. Coaching, stress management training. motivational talks, time management exercises, positive psychology activities, and individual behavior or imitational strategy (Jamieson \& Tuckey, 2017; Pignata, Boyd, Gillespie, Provis \& Winefield, 2016; David, Ionicioiu, Imbărus \& Sava, 2016; Avey, Luthans, Smith \& Palmer, 2010; Sin \& Lyubomirsky, 2009; Kirk \& Brown, 2003; Martin, Karanika-Murray, Biron \& Sanderson, 1999), are examples of organizational counseling interventions that can be carried out in order to manage individual employee's emotional and psychological well-being which in return would help to increase one's work performance (Weiss et al., 2016; Carmichael, Fenton, Roncancio, Sadhra \& Sing, 2014; Schaufeli, Taris \& Rhenen, 2008).

While evidence in the domain of human resource development has begun to demonstrate beneficial engagement for the performance of an individual employee is an important psychological experience linking the practices with worker results (Dubreuil, Forest, Gillet, Fernet, Thibault-Landry, Crevier-Braud \& Girouard, 2016; Fletcher, 2015; Cheng, 2012) in other countries, various counseling interventions have been carried out in order to assist low-performing civil servants in Malaysia. These interventions include mental and physical health guidance, and self-developmental and financial counseling services, which are combined into a designated Employee Assistance Program (EAP) known as the 'Self-Change and Well-Being Program'. This program is specifically tailored to help pool of low-performing (based on the annual performance appraisal marks of low than 60\%) civil servants to gradually improve their self-attitudes and work performance. However, the current module used in this program is not being validated for quite sometimes; hence, it's impacted in terms of effectiveness cannot be scientifically determined. In a recent development, the 'SELF-IE (Self Improvement Employee)' module is introduced as the newest counseling psychology intervention in this program, in order to enhance the participants' self-change in domains of emotional stability, psycho-spirituality, and behavioral adjustment (Bakar, Hassan \& Amat, 2020), in a short period of time.

The 'SELF-IE' module is built based on the integration of the Transtheoretical Model (TTM), and Reality Therapy Theory (Hutchison, Breckon, \& Johnston, 2009; Prochaska, 2008; Glasser, 1965). In comparison to the current module which focuses on five constructs to be measured, this 'SELF-IE Module' puts emphasis on three important variables to reflect the self-change of an individual low-performing civil servant, namely, the emotional stability, psycho-spiritual, and behavior adjustment. This emphasis is aligned with previous studies which indicated that these three elements are vital for self-improvement and work performance enhancement in any Employee Assistance Programs (EAP) to be developed (Wihler, Meurs, Momm, John \& Blickle, 2017; Jafari, 2016; Kossek, 2016; Sony \& Mekoth, 2016; Carmichael et al., 2014). Other scholars also agreed that these three elements are critically needed to improve the work performance of staff in any particular organizational setting (Tenney, Poole \& Diener, 2016; Moynihan \& Pandey, 2010; Cunningham, Woodward, Shannon, Macintosh, Lendrum, Rosenbloom \& Brown, 2002).

The current module used by PSD as an intervention in the 'Self-Change and Well-Being Program' is lacking in validation study since being introduced in 2013 (Hassan, Bakar \& Amat, 2019); hence, 'SELF-IE' module is adapted in order to enhance the whole impact of the intervention in helping the low-performing civil servant who participated in the program. Nonetheless, the impact of the module has never been assessed since its' inception; therefore, this study is designed to examine such an impact on the three measured variables. These variables are essential to overall employees' performance in the workplace (Bakar et al., 2020; Hassan et al., 2019; Tenney et al., 2016); thus, need to be measured after the intervention using 'SELF-IE' module has taken place. In doing so, the research has three alternative hypotheses to be tested:

$\mathbf{H}_{\mathbf{a}} \mathbf{1}$ : There is a significant mean difference in the emotional stability between the control group and the experimental group.

$\mathbf{H}_{\mathbf{a}}$ 2: There is a significant mean difference in the psycho-spirituality between the control group and the experimental group.

$\mathbf{H}_{\mathbf{a}}$ 3: There is a significant mean difference in the behavioral adjustment between the control group and the experimental group.

\section{METHODOLOGY}

This is a quantitative study, employing the quasi-experimental design which has pre-test, post-test, and follow-up test phases, conducted on control and experimental groups (Creswell, 2003). It is designed to look at the causal relationships and effects of the program's intervention ('SELF-IE' module), which took a total of 20-hours of activities. The program is conducted for three days and two nights, by selected psychology officers who have been trained to facilitate the 'SELF-IE' module.

A total of 68 low-performing civil servants who attended the 2017 'Self-Change and Well-Being Program' were roped as the study's respondents using the purposive sampling procedure. The Personal Well-Being Questionnaire (PWQ) is 
used as an instrument to collect data from the respondents at all phases of data collection. The instrument comprises 60 items, divided into six sections. Section A consists of nine items to record demographic information of the respondents, whereas sections B, C, D, E, and F have a total of 51 items on a 5-point Likert scale. This instrument has an overall Alpha Cronbach's value of 0.95 , which reflects its' high validity and reliability (Gay, Mills \& Airasian, 2011; Bond \& Fox, 2007).

Data was inferentially analyzed, using an independent t-test method, to find the mean differences of the all three measured variables for both control and experimental groups. The analysis was conducted using the Statistical Package for Social Sciences (SPSS) software, version 23.0.

\section{RESULTS/FINDINGS}

At the significant level of $p<.05$, all three measured variables showed significant differences in the mean between both control and experimental groups in the independent t-tests conducted. For the emotional stability construct, Table 1 illustrated that the mean for the experimental group $(\mu=3.7464)$ was higher than the mean for the control group $(\mu=$ 3.5313). Similarly, as shown in Table 2, there was a significant mean difference for the psycho-spirituality domain in which the mean for the experimental group $(\mu=4.1914)$ was higher than the control group's $(\mu=3.9970)$. Last but not least, a significant mean difference also occurred for the behavioral adjustment variable (as indicated in Table 3), in which the mean for the experimental group $(\mu=4.2413)$ exceeded the value for the control group $(\mu=4.0828)$. In a nutshell, all these findings made the three alternative hypotheses of this study were accepted.

Table 1: Mean Difference between Control and Experimental Groups for Emotional Stability

\begin{tabular}{ccccccc}
\hline Group & $\mathbf{N}$ & Mean $(\boldsymbol{\mu})$ & SD & t & $\boldsymbol{d} \boldsymbol{f}$ & Sig. \\
\hline Control & 33 & 3.5313 & .20172 & 2.483 & 66 & $.000^{*}$ \\
\hline Experimental & 35 & 3.7464 & .45726 & & & \\
\hline
\end{tabular}

*significant at $\mathrm{p}<.05$

Table 2: Mean Difference between Control and Experimental Groups for Psycho-Spirituality

\begin{tabular}{ccccccc}
\hline Group & $\mathbf{N}$ & Mean $(\boldsymbol{\mu})$ & SD & $\mathbf{t}$ & $\boldsymbol{d} \boldsymbol{f}$ & Sig. \\
\hline Control & 33 & 3.9970 & .28005 & 1.159 & 66 & $.000 *$ \\
\hline Experimental & 35 & 4.1914 & .49252 & & & \\
\hline
\end{tabular}

*significant at $\mathrm{p}<.05$

Table 3: Mean Difference between Control and Experimental Groups for Behavioral Adjustment

\begin{tabular}{ccccccc}
\hline Group & $\mathbf{N}$ & Mean $(\boldsymbol{\mu})$ & SD & t & $\boldsymbol{d} \boldsymbol{f}$ & Sig. \\
\hline Control & 33 & 4.0828 & .28773 & 2.541 & 66 & $.001 *$ \\
\hline Experimental & 35 & 4.2413 & .48916 & & & \\
\hline
\end{tabular}

*significant at $\mathrm{p}<.05$

\section{DISCUSSION/ANALYSIS}

The findings of this study indicated that there is a positive impact of applying the 'SELF-IE' module as an intervention in the 'Self-Change and Well-Being Program' to assist identified low-performing civil servants to holistically improve themselves and their work performance. The significant mean differences in all the three measured variables between the experimental group and control group proved that respondents who received the intervention did show improvement after being tested again with PWQ at post-test and follow up test phases.

First, after the intervention, respondents in the experimental group showed a significant increase of mean in the emotional stability domain. This finding is aligned with the study's finding done by Cunningham et al. (2002) which found that after an Employee Assistance Program (EAP) for hospital employees, there was a good change in emotional stability and work performance of the participants. This finding is also concurrent with Judge and Erez (2007), and Dubreuil et al. (2016) research works that found highly stable emotional state correlates directly with individual employee's work performance. The fact that emotion can be enhanced by using an intervention at the workplace which integrates the Transtheoretical Model approach (Goodwin, Cairns, Dargay \& Hanly, 2004), suggests that 'SELF-IE Module' is a good intervention since it is developed by integrating Transtheoretical Model (TTM) and Reality Therapy.

Secondly, the significant mean difference experienced by experiment group respondents proved that they started to appreciate their own psycho-spirituality value after the intervention. This is consistent with the view by Chandler, Holden, and Kolander (1992) which stated that employee who is aware of his or her spiritual values will strive to maintain harmony between colleagues and teams at work setting. This finding is also supported by findings from previous studies which indicated that elements of psychology and spirituality should be blended for developing an effective treatment program for work development, employees' recovery, and workers' well-being (King \& Haar, 2017; McCarthy, Bauer, Truxillo, Campion, Iddekinge \& Campion, 2017; Brown, Marquis \& Guiffrida, 2013). 
Finally, the improvement showed by experimental group respondents after receiving the intervention demonstrates that low-performing employees can still be assisted to change their behavior positively so that their workplace performance can also be enhanced. Kirk and Brown (2003), and Myers et al. (2000) pointed out that positive working behaviors could be instilled via a good counseling psychology intervention, in terms of any Employee Assistance Programs (EAPs). This view is also aligned with other scholars' opinions that organizational/industrial psychology training are essential to attune maladaptive behavior of employees so that their work performance could be rectified (Weiss et al., 2016; $\underline{\text { Sin \& }}$ Lyubomirsky, 2009; Martin et al., 1999; Richardson, 1993).

In this sense, it is safe to say that the intervention conducted using the 'SELF-IE' module has clearly produced an impact to improve these domains of self-change among respondents. The development of the module based on the integration of Prochaska's Transtheoretical Model (TTM) and Glasser's Reality Therapy put a strong emphasis on the holistic process of human changes via the strengthening of measured variables. This research's finding - all alternative hypotheses were accepted - indicated that this psychoeducational module contributed to the improvement of respondents' overall selfesteem, which will positively affect their work performance in their next appraisal (will be completed six months after the completion of the program).

\section{CONCLUSION}

In a nutshell, the counseling psychology intervention using the 'SELF-IE' module is really helping the low-performing civil servants to make self-change and enhance work performance in three vital dimensions; namely, emotional stability, psycho-spirituality, and behavioral adjustment, as established by this research's findings. The development of the 'SELF-IE' module not only validates and enhances the currently used module in Malaysian PSDs employee assistance program to help low-performing civil servants, but also contributes to the enrichment of human resource training modules as a whole, especially for government ministries, agencies, and other public organizations.

\section{LIMITATION AND STUDY FORWARD}

This study is conducted within the Putrajaya vicinity (using a purposive sampling technique), whereby the respondents were coming from ministries and agencies surrounding the area only. In the future, it is suggested that the respondents shall be randomly selected from other areas; for instance, different states and geographical locations, so that the crosscultural factors which may affect their work performance can be studied in the research.

In addition, it is also recommended for future researchers to explore other variables to widen the understanding of employees' performance as a whole. This is due to the fact that other potential variables such as cognitive ability, social skills' capability, and workplace condition were also studied in previous research works about employees' job performance in various organizational settings.

\section{ACKNOWLEDGMENT}

Researchers are grateful to the Psychology Unit of Malaysian Public Service Department (PSD), ministries and agencies involved, and also the Faculty of Education (Counselling and Guidance Program), Universiti Kebangsaan Malaysia (Research Grant Code: GG-2019-028). Contribution of all parties mentioned had warranted this research work to be completed on time and successfully achieved its objective.

\section{AUTHORS CONTRIBUTION}

Abu Yazid Abu Bakar is a senior lecturer at the Faculty of Education, Universiti Kebangsaan Malaysia (UKM). He is the main/corresponding author of this article, and also the main supervisor for Hazaila Hassan's doctoral research.

Hazaila Hassan is a psychology officer at the Malaysian Public Service Department (PSD), and a doctoral candidate at the Faculty of Education, Universiti Kebangsaan Malaysia. She is the co-author of this article due to the fact that this article is written using data from her doctoral thesis.

Salleh Amat is an associate professor at the Faculty of Education, Universiti Kebangsaan Malaysia (UKM). He is a cosupervisor for Hazaila Hassan's doctoral research which entitles him as the co-author for this article.

\section{REFERENCES}

1. Avey, J. B., Luthans, F., Smith, R. M., \& Palmer, N. F. (2010). Impact of positive psychological capital on employee well-being over time. J Occup Health Psychol, 15(1), 17-28. https://doi.org/10.1037/a0016998

2. Bakar, A. Y. A., Hassan, H., \& Amat, S. (2020). The reliability study of Personal Wellness Questionnaire (PWQ) to measure self-changes among Malaysian low-performing public service officers. International Journal of Academic Research in Business and Social Sciences, 10(1), 350-360. https://doi.org/10.6007/IJARBSS/v10-i1/6855

3. Bandura, A. (1982). Self-efficacy mechanism in human agency. American Psychologist, 37(2), 122-147. https://doi.org/10.1037/0003-066X.37.2.122

4. Bond, T. G., \& Fox, C. M. (2007). Applying the Rasch Model: Fundamental measurement in the human Sciences $\left(2^{\text {nd }}\right.$ Ed. $)$. Erlbaum. 
5. Brown, A. P., Marquis, A., \& Guiffrida, D. A. (2013). Mindfulness-based interventions in counseling. Journal of Counseling and Development, 91(1), 96-104. https://doi.org/10.1002/j.1556-6676.2013.00077.x

6. Carmichael, F., Fenton, S-J., Roncancio, M. P., Sadhra, S., \& Sing, M. (2014). Workplace wellbeing programmes and their impact on employees and their employing organisations: A scoping review of the evidence base. Birmingham Business School Discussion Paper Series, The University of Birmingham.

7. Caroll, M. (1996). Workplace counselling: A systematic approach to employee care. SAGE Publications Ltd.

8. Chandler, C. K., Holden, J. M., \& Kolander, C. A. (1992). Counseling for spiritual wellness: Theory and practice. Journal of Counseling \& Development, 71(2), 168-175. https://doi.org/10.1002/j.15566676.1992.tb02193.x

9. Cheng, F. K. (2012). Workplace counseling in Hong Kong: A pilot study. Journal of International Social Issues, 1(1), 87-105.

10. Creswell, J. W. (2003). Research design: Qualitative, quantitative and mixed methods approach. SAGE Publications.

11. Cunningham, C. E., Woodward, C. A., Shannon, H. S., Macintosh, J., Lendrum, B., Rosenbloom, D., \& Brown, J. (2002). Readiness for organizational change: A longitudinal study of workplace, psychological and behavioural correlates, Journal of Occupational and Organizational Psychology, 75(4), 377-392. https://doi.org/10.1348/096317902321119637

12. David, O. A., Ionicioiu, I., Imbăruş, A. C., \& Sava, F. A. (2016). Coaching banking managers through the financial crisis: Effects on stress, resilience, and performance. Journal of Rational-Emotive \& CognitiveBehavior Therapy, 34, 267-281. https://doi.org/10.1007/s10942-016-0244-0

13. Dubreuil, P., Forest, J., Gillet, N., Fernet, C., Thibault-Landry, A., Crevier-Braud, L., \& Girouard, S. (2016). Facilitating well-being and performance through the development of strengths at work: Results from an intervention program. International Journal of Applied Positive Psychology, 1, 1-19. https://doi.org/10.1007/s41042-016-0001-8

14. Fletcher, L. (2015). Training perceptions, engagement, and performance: Comparing work engagement and personal role engagement. Human Resource Development International, 19(1), 4-26. https://doi.org/10.1080/13678868.2015.1067855

15. Gay, L. R., Mills, G. E., \& Airasian, P. W. (2011). Educational research: Competencies for analysis and applications. Pearson Higher Education.

16. Glasser, W. (1965). Reality therapy. HarperCollins.

17. Goodwin, P., Cairns, S., Dargay, J., Hanly, M., Parkhurst, G., Stokes, G., \& Vythoulkas, P. (2004). Changing travel behaviour. ESRC Transport Studies Unit, University College, London, London, pp. 1-48 http://www2.cege.ucl.ac.uk/cts/tsu/conference/

18. Hassan, H., Bakar, A. Y. A., \& Amat, S. (2019). The validity and reliability of Well-Being Questionnaire (WBQ) for measuring behavioral changes of low-performing civil servants in Malaysia. International Journal of Academic Research in Business and Social Sciences, 9(3), 599-608. https://doi.org/10.6007/IJARBSS/v9$\underline{\mathrm{i} 3 / 5729}$

19. Hutchison, A. J., Breckon, J. D., \& Johnston, L. H. (2009). Physical activity behavior change interventions based on the Transtheoretical Model: A systematic review. Health Educ. Behav., 36(5), 829-845. https://doi.org/10.1177/1090198108318491

20. Jabatan Perkhidmatan Awam Malaysia. (2005). Pekeliling Perkhidmatan No. 18: Aplikasi Psikologi dalam Perkhidmatan Awam.

21. Jafari, S. (2016). Religion and spirituality within counselling/clinical psychology training programmes: A systematic review. British Journal of Guidance \& Counselling, 44(3), 257-267. https://doi.org/10.1080/03069885.2016.1153038

22. Jamieson, S. D., \& Tuckey, M. R. (2017). Mindfulness interventions in the workplace: A critique of the current state of the literature. J Occup Health Psychol, 22(2), 180-193. https://doi.org/10.1037/ocp0000048

23. Judge, T. A., \& Erez, A. (2007). Interaction and intersection: The constellation of emotional stability and extraversion in predicting performance, Personnel Psychology, 60(3), 573-596. https://doi.org/10.1111/j.17446570.2007.00084.X

24. King, E., \& Haar, J. M. (2017). Mindfulness and job performance: A study of Australian leaders. Asia Pacific Journal of Human Resources, 55(3), 298-319. https://doi.org/10.1111/1744-7941.12143

25. Kirk, A. K., \& Brown, D. F. (2003). Employee assistance programs: A review of the management of stress and wellbeing through workplace counselling and consulting. Australian Psychologist, 38(2), 138-143. https://doi.org/10.1080/00050060310001707137

26. Kossek, E. E. (2016). Implementing organizational work-life interventions: Toward a triple bottom line. Community Work \& Family, 19(2), 242-256. https://doi.org/10.1080/13668803.2016.1135540

27. Marsidi, A., \& Latip, H. A. (2007). Faktor-faktor yang mempengaruhi komitmen pekerja di organisasi awam. Jurnal Kemanusiaan, 10, 56-64.

28. Martin, A., Karanika-Murray, M., Biron, C., \& Sanderson, K. (1999). The psychosocial work environment, employee mental health, and organizational interventions: Improving research and practice by taking a multilevel approach. Stress Health, 32(3), 201-215. https://doi.org/10.1002/smi.2593 
29. McCarthy, J. M., Bauer, T. N., Truxillo, D. M., Campion, M. C., Iddekinge, C. H. V., \& Campion, M. A. (2017). Using pre-test explanations to improve test-taker reactions: Testing a set of "wise" interventions. Organizational Behavior and Human Decision Processes, 141, 43-56. https://doi.org/10.1016/j.obhdp.2017.04.002

30. Moynihan, D. P., \& Pandey, S. K. (2010). The big question for performance management: Why do managers use performance information? Journal of Public Administration Research and Theory, 20(4), 849-866. https://doi.org/10.1093/jopart/muq004

31. Myers, J. E., Sweeney, T. J., \& Witmer, J. M. (2000). The Wheel of Wellness counseling for wellness: A holistic model for treatment planning. Journal of Counseling \& Development, 78(3), 251266. https://doi.org/10.1002/j.1556-6676.2000.tb01906.x

32. Pignata, S., Boyd, C., Gillespie, N., Provis, C., \& Winefield, A. H. (2016). Awareness of stress-reduction interventions: The impact on employees' well-being and organizational attitudes. Stress Health, 32(3), 231243. https://doi.org/10.1002/smi.2597

33. Prochaska, J. O. (2008). Decision making in the Transtheoretical Model of behavior change. Medical Decision Making, 28(6), 845-849. https://doi.org/10.1177/0272989X08327068

34. Richardson, M. S. (1993). Work in people's lives: A location for counseling psychologists. Journal of Counseling Psychology, 40(4), 425-433. https://doi.org/10.1037/0022-0167.40.4.425

35. Schaufeli, W. B., Taris, T. W., \& Rhenen, W. V. (2008). Workaholism, burnout, and work engagement: Three of a kind or three different kinds of employee well-being? Applied Psychology: An International Review, 57(2), 173-203. https://doi.org/10.1111/j.1464-0597.2007.00285.x.x

36. Sin, N. L., \& Lyubomirsky, S. (2009). Enhancing well-being and alleviating depressive symptoms with positive psychology interventions: A practice-friendly meta-analysis. $J$ Clin Psychol, 65(5), 467-487. https://doi.org/10.1002/jclp.20593

37. Sony, M., \& Mekoth, N. (2016). The relationship between emotional intelligence, frontline employee adaptability, job satisfaction, and job performance. Journal of Retailing and Consumer Services, 30, 20 -32. https://doi.org/10.1016/j.jretconser.2015.12.003

38. Tenney, E. R., Poole, J. M., \& Diener, E. (2016). Does positivity enhance work performance?: Why, when, and what we don't know. Research in Organizational Behavior, 36, 27-46. https://doi.org/10.1016/j.riob.2016.11.002

39. Weiss, L. A., Westerhof, G. J., \& Bohlmeijer, E. T. (2016). Can we increase psychological well-being? The effects of interventions on psychological well-being: A meta-analysis of randomized controlled trials. PLoS One, 11(6), 1-16. https://doi.org/10.1371/journal.pone.0158092

40. Wihler, A., Meurs, J. A., Momm, T. D., John, J., \& Blickle, G. (2017). Conscientiousness, extraversion, and field sales performance: Combining narrow personality, social skill, emotional stability, and nonlinearity. Personality and Individual Differences, 104, 291-296. https://doi.org/10.1016/j.paid.2016.07.045 